\title{
Lung cancer in asbestos cement workers in Denmark
}

\author{
Edith Raffn, Ebbe Villadsen, Gerda Engholm, Elsebeth Lynge
}

\begin{abstract}
Objectives-To study the relative and absolute risks of main types of lung cancer in a cohort of asbestos cement workers from Denmark.

Methods-A cohort of 7887 men and 576 women employed between 1928 and 1984 was compiled from the personnel files of Danish Eternit Production. The cohort was followed up for deaths, emigrations, and incident cancer cases during the period $1943-90$. The observed number of lung cancer cases in the cohort was compared with the expected number based on incidences for the Danish population. Internal comparison was made with Poisson modelling.

Results-A total of 226 lung cancer cases were observed (223 men and three women). The standardised incidence ratio (SIR) for all lung cancer among men was 1.7 (observed number 223, expected number $129 \cdot 7,95 \%$ confidence interval (95\% CI) $1 \cdot 5-2 \cdot 0)$. The SIRs were raised for all main types of lung cancer; adenocarcinoma $2 \cdot 6$, squamous cell carcinoma $1 \cdot 7$, and anaplastic carcinoma $1 \cdot 5$. The higher SIR for adenocarcinomas was found particularly with a latency period of 25 years or more. Among the 93 excess lung cancer cases, 36 were squamous cell carcinomas and 32 were adenocarcinomas.

Conclusion-Asbestos cement work is associated with an increased risk of lung cancer of all main types. During the first 25 years after the start of employment this excess risk is shared almost equally between the different histological types of lung cancer, but the risk of adenocarcinomas is clearly higher after this point.
\end{abstract}

(Occup Environ Med 1996;53:399-402)

Society,

Strandboulevarden 49 ,

DK-2100 København

Ø, Denmark

Edith Raffn

Ebbe Villadsen

Gerda Engholm

Elsebeth Lynge

Clinic of Occupational

Medicine, Helsevej 2,

DK-3400 Hillerød,

Denmark

Edith Raffn

Correspondence to:

Dr Elsebeth Lynge, Danish

Cancer Society,

Strandboulevarden 49

DK-2100 Kobenhavn

Denmark.

Accepted 11 January 1996

Keyword: asbestos cement; lung cancer incidence; Denmark; histological type; latency

In 1993, we reported on the incidence of lung cancer by histological type in a cohort of asbestos cement workers from Denmark for the period 1943-84. ${ }^{1}$ A standardised incidence ratio (SIR) of 3.3 was found for adenocarcinomas of the lung, whereas SIRs of $1 \cdot 7,1 \cdot 6$, and $1 \cdot 6$, respectively, were found for squamous cell carcinomas, anaplastic carcinomas, and for unspecified malignant lung tumours. We therefore concluded that the relation between asbestos exposure and lung cancer was stronger for adenocarcinomas than for the other histological types. Järvholm ${ }^{2}$ argued that the result could be biased as we had included only lung cancer cases diagnosed 15 years or more since the date of first employment and anaplastic carcinomas may grow faster than adenocarcinomas. Järvholm also asked for data on the absolute risks for the different types of lung cancer.

In reply to this criticism we report here on both the relative and the absolute risks calculated both with and without a 15 year latency period for specific types of lung cancer in the Danish cohort of asbestos cement workers. The data have been updated to include all incident lung cancer cases diagnosed in the period 1943-90.

\section{Material and methods}

In Denmark, all asbestos cement products were manufactured by Danish Eternit Production which began in 1928. The main products were building materials such as corrugated roofings, fittings and mouldings, flat roofing sheets, plates for covering external and internal walls, acoustic sealings, and pipes. The asbestos fibre content in the products have ranged from $5 \%$ to $20 \%$.

From 1928 to 1940 only chrysotile was used. During the second world war paper replaced asbestos in the production. Amosite was introduced in 1946, and small amounts of crocidolite were used between 1952 and 1968 . However, chrysotile in total made up $90 \%$ of the asbestos used in the factory.

Measurements of atmospheric asbestos particles were made during the feeding of the mill and the forming vessel and during unloading of containers in 1948 and 1957. Based on these measurements, The Danish National

Table 1 Vital status by 31 December 1990 for the cohort employed in 1928-84 at Danish Eternit Production

\begin{tabular}{lrrr}
\hline & Men & Women & Total \\
\hline Excluded from the analysis: & & & \\
$\quad$ Not identified & 26 & 6 & 32 \\
Employed only 1941-4 & 17 & 0 & 17 \\
Only short term employment & & & \\
$\quad$ divided into several periods or & & & \\
$\quad$ dead before first employment & 49 & 1 & 50 \\
$\quad$ Dead or emigrated before 1943 & 17 & 1 & 18 \\
Included in the analysis: & & & \\
Alive 31 December 1990 & 5849 & 504 & 6353 \\
Dead 1943-90 & 1867 & 65 & 1932 \\
Emigrated 1943-90 & 167 & 7 & 174 \\
Disappeared 1943-90 & 4 & 0 & 4 \\
Total & 7996 & 584 & 8580 \\
\hline
\end{tabular}


Table 2 Observed and expected number of lung cancer cases 1943-90 in the cohort of men employed at Danish Eternit Production by years since first employment

\begin{tabular}{|c|c|c|c|c|c|c|c|c|c|c|c|c|c|c|c|c|}
\hline \multirow[b]{3}{*}{ Type of lung cancer } & \multicolumn{16}{|c|}{ Years since first employment } \\
\hline & \multicolumn{4}{|c|}{$0-14 y$} & \multicolumn{4}{|c|}{$15-24 y$} & \multicolumn{4}{|c|}{$25-34 y$} & \multicolumn{4}{|c|}{$\geqslant 35 y$} \\
\hline & Obs & $\operatorname{Exp}$ & SIR & $(95 \% C I)$ & Obs & $\operatorname{Exp}$ & SIR & $(95 \% C I)$ & Obs & $\operatorname{Exp}$ & SIR & $(95 \% C I)$ & $\overline{O b s}$ & $\operatorname{Exp}$ & SIR & $(95 \% C I)$ \\
\hline $\begin{array}{l}\text { All lung } \\
\text { Unspecified } \\
\text { Adenocarcinoma } \\
\text { Squamous cell } \\
\text { Anaplastic } \\
\text { Other }\end{array}$ & $\begin{array}{r}61 \\
6 \\
10 \\
27 \\
15 \\
3\end{array}$ & $\begin{array}{r}35 \cdot 6 \\
5 \cdot 9 \\
4 \cdot 7 \\
13 \cdot 9 \\
9 \cdot 7 \\
1 \cdot 4\end{array}$ & $\begin{array}{l}1 \cdot 7 \\
1 \cdot 0 \\
2 \cdot 1 \\
2 \cdot 0 \\
1 \cdot 5 \\
2 \cdot 1\end{array}$ & $\begin{array}{l}(1 \cdot 3-2 \cdot 2) \\
(0 \cdot 4-2 \cdot 2) \\
(1 \cdot 0-3 \cdot 9) \\
(1 \cdot 3-2 \cdot 8) \\
(0 \cdot 9-2 \cdot 6) \\
(0 \cdot 4-6 \cdot 1)\end{array}$ & $\begin{array}{r}66 \\
7 \\
14 \\
28 \\
15 \\
2\end{array}$ & $\begin{array}{r}42 \cdot 8 \\
8 \cdot 4 \\
7 \cdot 2 \\
15 \cdot 7 \\
10 \cdot 3 \\
1 \cdot 3\end{array}$ & $\begin{array}{l}1.5 \\
0.8 \\
1.9 \\
1.8 \\
1.5 \\
1.6\end{array}$ & $\begin{array}{l}(1 \cdot 2-2 \cdot 0) \\
(0 \cdot 3-1 \cdot 7) \\
(1 \cdot 1-3 \cdot 3) \\
(1 \cdot 2-2 \cdot 6) \\
(0 \cdot 8-2 \cdot 4) \\
(0 \cdot 2-5 \cdot 8)\end{array}$ & $\begin{array}{r}63 \\
16 \\
19 \\
14 \\
14 \\
0\end{array}$ & $\begin{array}{r}30 \cdot 1 \\
6 \cdot 1 \\
5 \cdot 0 \\
11 \cdot 1 \\
7 \cdot 2 \\
0 \cdot 8\end{array}$ & $\begin{array}{l}2 \cdot 1 \\
2 \cdot 6 \\
3 \cdot 8 \\
1 \cdot 3 \\
2 \cdot 0 \\
\end{array}$ & $\begin{array}{l}(1 \cdot 6-2 \cdot 7) \\
(1 \cdot 5-4 \cdot 3) \\
(2 \cdot 3-6 \cdot 0) \\
(0 \cdot 7-2 \cdot 1) \\
(1 \cdot 1-3 \cdot 3) \\
-\end{array}$ & $\begin{array}{r}33 \\
4 \\
9 \\
15 \\
5 \\
0\end{array}$ & $\begin{array}{r}21 \cdot 1 \\
5 \cdot 0 \\
3 \cdot 2 \\
7 \cdot 8 \\
4 \cdot 7 \\
0 \cdot 4\end{array}$ & $\begin{array}{l}1.6 \\
0 \cdot 8 \\
2.8 \\
1.9 \\
1.1 \\
\end{array}$ & $\begin{array}{l}(1 \cdot 1-2 \cdot 2) \\
(0 \cdot 2-2 \cdot 0) \\
(1 \cdot 3-5 \cdot 3) \\
(1 \cdot 1-3 \cdot 2) \\
(0 \cdot 3-2 \cdot 5) \\
\end{array}$ \\
\hline
\end{tabular}

Institute of Occupational Health has estimated that the concentration in 1948 varied between 50 and 800 fibres per millilitre $(\mathrm{f} / \mathrm{ml})$, and in 1957 between 10 and $100 \mathrm{f} / \mathrm{ml}$ (Thomas Schneider, personal communication). In $1973,41 \%$ of the exposure measurements were recorded as being above $2 \cdot 0 \mathrm{f} / \mathrm{ml}$.

Information on people employed between 1928 and 1984 was extracted from the personnel files of the company. Job titles were available only for people employed in 1928-41. People employed only in 1941-4, when no asbestos was used, were excluded from the analysis.

The cohort was followed up until the end of 1990. Information on vital status and emigrations was obtained from the population registers. Person-years at risk were calculated from 1 January 1943 or date of first employment whichever came last until date of death, emigration, or 31 December 1990 whichever came first.

Information on incident cancer cases during the period 1943-90 was obtained from the national cancer register. All incident cancer cases diagnosed within the individual risk periods were included in the analysis. Between 1943 and 1977 all lung cancers were coded according to a modified version of the seventh revision of the international classification of diseases (ICD-7) 4 in which a distinction was made between histologically verified subgroups of lung cancer. Since 1978 all lung cancers have been coded according to the oncology revision of the ICD (ICD-O). ${ }^{5}$ Expected number of cases of lung cancer divided into histological subtypes were calculated based on the sex, age, and calender year specific incidences for the total Danish population. The $95 \%$ confidence intervals (95\% CIs) for the SIRs were calculated with Byar's approximation for the $x^{2}$ distribution. ${ }^{6}$ Dependence of the lung cancer incidence on year of first employment, duration of employment, and time since first employment was analysed with Poisson regression models with the log of the expected number of cases (from the population rates, as described above) as an offset variable. The method is described by Breslow and Day. ${ }^{7}$ The stastistical package Epicure $^{8}$ was used.

\section{Results}

The study included 7887 men and 576 women (table 1). The present analysis for 1943-90 includes a total of 226 lung cancers whereas only 164 lung cancers were included in our previous analysis covering the period
1943-84. Only three cases were found among the women, and the results are therefore reported for men only.

The SIR for all lung cancer for the entire observation period was $1.7(95 \%$ CI $1 \cdot 5-2 \cdot 0)$. The SIRs were increased for all main types of lung cancer, 2.6 (95\% CI 1.9-3.4) for adenocarcinomas, $1 \cdot 7(95 \%$ CI $1 \cdot 4-2 \cdot 2)$ for squamous cell carcinomas, and 1.5 (95\% CI 1.1-2.0) for anaplastic carcinomas. These SIRs were only marginally changed when the analysis was restricted to observations 15 or more years after the start of employment. However, high SIRs were found in particular cases 25 years or more after start of employment which contributed to the higher SIR for adenocarcinomas (table 2, fig 1 ).

The male asbestos cement workers in total developed 223 cases of lung cancer, whereas 130 cases were expected based on the incidences for Danish men. This is a difference of 93 cases, of which 36 cases were squamous cell carcinomas, 32 adenocarcinomas, and 17 anaplastic carcinomas.

Table 3 shows the results of the Poisson modelling of the lung cancer incidence data by year of first employment, duration of employment, and years since first employment. Increased risks at the borderline of significance were found only for unspecified lung cancers and for adenocarcinomas 25-34 years since first employment.

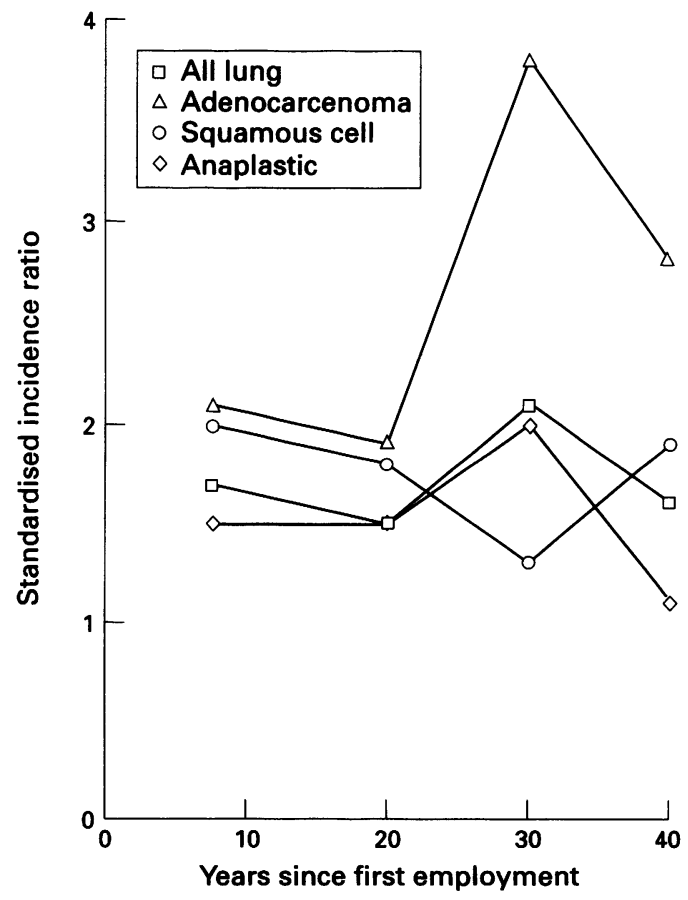

Lung cancer in asbestos cement workers in Denmark 1943-90. 


\begin{tabular}{|c|c|c|c|}
\hline Obs & Exp & $S I R$ & $(95 \% C I)$ \\
\hline $\begin{array}{r}223 \\
33 \\
52 \\
84 \\
49 \\
5\end{array}$ & $\begin{array}{r}129.7 \\
25.5 \\
20.1 \\
48.4 \\
31.9 \\
3.9\end{array}$ & $\begin{array}{l}1 \cdot 7 \\
1.3 \\
2.6 \\
1.7 \\
1.5 \\
1.3\end{array}$ & $\begin{array}{l}(1 \cdot 5-2 \cdot 0) \\
(0 \cdot 9-1 \cdot 8) \\
(1 \cdot 9-3 \cdot 4) \\
(1 \cdot 4-2 \cdot 2) \\
(1 \cdot 1-2 \cdot 0) \\
(0 \cdot 4-3 \cdot 0)\end{array}$ \\
\hline
\end{tabular}

Table 3 Relative risk of lung cancer 1943-90 in the cohort of men employed at Danish Eternit Production by year of first employment, duration of employment, and years since first employment (results of analysis with multiplicative Poisson model)

\begin{tabular}{|c|c|c|c|c|c|c|c|c|c|c|}
\hline & \multicolumn{2}{|c|}{ All lung cancers } & \multicolumn{2}{|c|}{$\begin{array}{l}\text { Unspecified } \\
\text { lung cancer }\end{array}$} & \multicolumn{2}{|c|}{ Adenocarcinomas } & \multicolumn{2}{|c|}{$\begin{array}{l}\text { Squamous cell } \\
\text { carcinomas }\end{array}$} & \multicolumn{2}{|c|}{$\begin{array}{l}\text { Anaplastic } \\
\text { carcinomas }\end{array}$} \\
\hline & $R R$ & $(95 \% C I)$ & $R R$ & $(95 \% C I)$ & $R R$ & $(95 \% C I)$ & $R R$ & $(95 \% C I)$ & $R R$ & $(95 \% C I)$ \\
\hline $\begin{array}{l}\text { Baseline compared with } \\
\text { Danish population }\end{array}$ & $1 \cdot 5$ & $0.9-2 \cdot 6$ & 0.9 & $0 \cdot 2-3 \cdot 6$ & 0.8 & $0 \cdot 2-3 \cdot 1$ & $2 \cdot 7$ & $1 \cdot 2-6 \cdot 2$ & $1 \cdot 4$ & $0 \cdot 5-4 \cdot 1$ \\
\hline $\begin{array}{l}\text { Year of first employment: } \\
1928-50 \\
1951-62 \\
1963-75\end{array}$ & $\begin{array}{l}1 \\
1 \cdot 2 \\
1 \cdot 0\end{array}$ & $\begin{array}{l}0.8-1.8 \\
0.6-1.8\end{array}$ & $\begin{array}{l}1 \\
1 \cdot 2 \\
0 \cdot 7\end{array}$ & $\begin{array}{l}0 \cdot 4-3 \cdot 0 \\
0 \cdot 1-3 \cdot 3\end{array}$ & $\begin{array}{l}1 \\
1 \cdot 9 \\
2 \cdot 2\end{array}$ & $\begin{array}{l}0 \cdot 7-5 \cdot 0 \\
0 \cdot 6-7 \cdot 7\end{array}$ & $\begin{array}{l}1 \\
0.8 \\
0.6\end{array}$ & $\begin{array}{l}0 \cdot 4-1 \cdot 7 \\
0 \cdot 2-1 \cdot 6\end{array}$ & $\begin{array}{l}1 \\
1 \cdot 1 \\
1 \cdot 2\end{array}$ & $\begin{array}{l}0 \cdot 4-2 \cdot 6 \\
0 \cdot 4-3 \cdot 9\end{array}$ \\
\hline $\begin{array}{l}\text { Duration of employment }(y) \text { : } \\
<1 \\
1-4 \\
\geqslant 5\end{array}$ & $\begin{array}{l}1 \\
0 \cdot 8 \\
1.0\end{array}$ & $\begin{array}{l}0 \cdot 5-1 \cdot 3 \\
0 \cdot 7-1 \cdot 4\end{array}$ & $\begin{array}{l}1 \\
1.0 \\
1.0\end{array}$ & $\begin{array}{l}0 \cdot 3-3 \cdot 1 \\
0 \cdot 7-2 \cdot 8\end{array}$ & $\begin{array}{l}1 \\
1.0 \\
1.4\end{array}$ & $\begin{array}{l}0 \cdot 4-2 \cdot 6 \\
0 \cdot 7-2 \cdot 8\end{array}$ & $\begin{array}{l}1 \\
0.6 \\
0.8\end{array}$ & $\begin{array}{l}0 \cdot 2-1 \cdot 5 \\
0 \cdot 5-1 \cdot 5\end{array}$ & $\begin{array}{l}1 \\
0 \cdot 7 \\
1.0\end{array}$ & $\begin{array}{l}0 \cdot 2-2 \cdot 2 \\
0 \cdot 5-2 \cdot 1\end{array}$ \\
\hline $\begin{array}{l}\text { Years since first employment: } \\
15-24 \\
25-34 \\
\geqslant 35\end{array}$ & $\begin{array}{l}1 \\
1 \cdot 3 \\
1 \cdot 1\end{array}$ & $\begin{array}{l}0 \cdot 9-2 \cdot 0 \\
0 \cdot 6-1 \cdot 8\end{array}$ & $\begin{array}{l}1 \\
2.6 \\
0.9\end{array}$ & $\begin{array}{l}0 \cdot 96-7 \cdot 3 \\
0 \cdot 2-3 \cdot 7\end{array}$ & $\begin{array}{l}1 \\
2 \cdot 3 \\
2 \cdot 4\end{array}$ & $\begin{array}{l}0 \cdot 98-5 \cdot 5 \\
0 \cdot 7-8 \cdot 2\end{array}$ & $\begin{array}{l}1 \\
0.6 \\
0.9\end{array}$ & $\begin{array}{l}0 \cdot 3-1 \cdot 2 \\
0 \cdot 4-2 \cdot 0\end{array}$ & $\begin{array}{l}1 \\
1.4 \\
0.8\end{array}$ & $\begin{array}{l}0 \cdot 6-3 \cdot 3 \\
0 \cdot 2-2 \cdot 7\end{array}$ \\
\hline
\end{tabular}

\section{Discussion}

These updated data from our cohort study of asbestos cement workers showed significantly increased risks for lung cancer of all histological types. During the first 25 years since the start of employment the excess risk was shared almost equally between the main histological types of lung cancer, but after the first 25 years the excess risk for adenocarcinomas was clearly higher than for the other histological types.

The SIR of 2.6 for adenocarcinomas was based on 32 extra lung cancer cases, whereas the smaller SIR of 1.7 for squamous cell carcinomas was based on 36 extra cases, thus indicating that squamous cell carcinoma is the leading histological type of lung cancer among men in Denmark. The SIR of 1.5 for anaplastic carcinomas was based on 17 extra cases. There were in total 49 observed cases of anaplastic carcinomas, of these 24 were diagnosed after 1978. According to the ICD-O codes used during this period 20 of these cases were small cell carcinomas (morphology code 8041·3).

In the present analysis, the rates of lung cancer for all Danish men were used for calculation of the expected number of cases. It is questionable whether all Danish men is a reasonable comparison group. However, Danish Eternit Production is in Årborg, a provincial town in nothern Jutland. The rates of lung cancer for men in provincial towns in Denmark are the same as those for all Danish men. ${ }^{9}$ The smoking habits of the employees at Danish Eternit Production have never been studied, but a cross sectional study of smoking habits in Ålborg in 1973 showed that asbestos cement workers had smoking habits similar to those of men in Ålborg in general, the percentages of present and past smokers (all types of tobacco) were $95 \%$ and $92 \%$, respectively. ${ }^{10}$

The Poisson modelling showed no pattern by year of first employment. This is supprising, as the estimated concentration of asbestos in the factory varied between 50 and $800 \mathrm{f} / \mathrm{ml}$ in 1948 and was mostly below $2 \mathrm{f} / \mathrm{ml}$ in 1973 . From 1953 to 1973 the percentage of cigarette smokers among men in Denmark increased from $23 \%$ to $41 \%,{ }^{11}$ and it could therefore be argued that we compare men first employed in
1928-50 with high asbestos exposure and low use of cigarettes with men first employed in 1963-75 with low asbestos exposure and high use of cigarettes. However, the national rates of lung cancer were used as offset variables in the analysis. It is therefore reasonable to conclude that employment in the factory both during the periods with high and lower asbestos concentration was associated with an increased risk of lung cancer, given that changes in the smoking habits over time among the asbestos workers were similar to those of the total population.

The Poisson modelling furthermore showed no pattern by duration of employment. It is, however, not surprising that duration of employment is a bad surrogate measure of accumulated dose of asbestos. The cohort includes different groups such as short term workers with dirty and dusty work tasks, a stable group of maintanence workers, and white collar workers with very little asbestos exposure. Job titles were recorded in the personnel files only for the small group of people employed in 1928-41.

It was thus not possible based on these weak proxy variables for exposure, year of first employment, and duration of employment, to identify a subgroup of workers with a risk of lung cancer above that of the total group of asbestos cement workers.

Data on the risk of lung cancer by histological types after exposure to asbestos are available from previous case-control and descriptive studies. Vainio and Boffetta recently analysed the data from seven of these studies and found a relative risk of $1.33(95 \%$ CI 1.00-1.76) for small cell carcinoma, of 0.93 (95\% CI 0.69-1.25) for adenocarcinoma, and of $0.83(95 \%$ CI $0.56-1 \cdot 23)$ for large cell carcinoma, when cases of squamous cell carcinoma were taken as the reference group. ${ }^{12}$ It should be noted, however, that among these studies was a Swedish case-control study where the exposed cases were asbestos cement workers from a cohort similar to the one covered by our study. This Swedish study showed a positive relation between asbestos exposure and adenocarcinomas. ${ }^{13}$ Among five other case-control studies ${ }^{14-18}$ only one found a 
clearly higher relative risk for adenocarcinoma than for squamous cell carcinoma. ${ }^{19}$

Previous studies overall, therefore, do not support the finding in our study of a higher risk of adenocarcinoma than of other types of lung cancer after asbestos exposure. To date, our study remains the only cohort study on this issue.

1 Raffn E, Lynge E, Korsgaard B. Incidence of lung cance by histological type among asbestos cement workers in Denmark. Brf Ind Med 1993;50:85-9.

2 Järvholm B. Letter to the editor. Br f Ind Med 1993;50:767.

3 Raffn E, Lynge E, Juel K, Korsgaard B. Incidence of cancer and mortality among industry in Denmark. Br $\mathcal{F}$ Ind Med 1989;46:90-6.

4 Clemmesen J. Statistical studies in the aetiology of malig nant neoplasms. I. Review and results. Kobenhavn: nant neoplasms. I. Review

5 World Health Organisation. ICD-O. International classification on oncology. Geneva: WHO, 1976.

6 Breslow NE, Day NE. The standardized mortality ratio. In: Sen PK, ed. Biostatistics in biomedical, public health and environmental sciences. North-Holland: Elsevier, 1985.

7 Breslow NE, Day NE. Statistical methods in cancer research. Vol II. The design and analysis of cohort studies. Lyon International Agency for Research on Cancer, 1987. (IARC Sci Publ No 82.)

8 Preston DL, Lubin JH, Pierce DA, McConney ME.
Epicure. Seattle, WA: Hirosoft International Corporation, 1993.

9 Clemmesen J. Statistical studies in malignant neoplasms. V. Trends and risks, Denmark 1945-77. Acta Pathol Microbiol Scand. 1977;(suppl 261):1-286.

10 Clemmesen J, Jensen HS. Cancer incidence among 5686 asbestos cement workers followed from 1943 through 1976. Ecotoxicol Environ Safety 1981;5:15-23.

11 Nielsen PE, Krarup NB, Astrup J, Gyntelberg F, Lisse O. Alterations in Danish smoking habits 1958-76. Ugeskr Laeg 1978;140:2528-32. (In Danish.)

12 Vainio $\mathrm{H}$, Boffetta P. Mechanisms of the combined effect of asbestos and smoking in the etiology of lung cancer. of asbestos and smoking in the etiology of lung

13 Johansson L, Albin M, Jakobsson K, Mikoczy Z. Histological type of lung carcinoma in asbestos cement workers and matched controls. Br F Ind Med 1992;49: 626-30.

14 Kjuus $\mathrm{H}$, Skjærven R, Langård S, Lien JT, Aamodt T. A case-referent study of lung cancer, occupational exposures, and smoking Scand $f$ Work Environ Health 1986;12:203-9.

15 Minowa $M$, Hatano S, Ashizawa $M$, Oguro $H$, Naruhashi $\mathrm{H}$, Suzuki $\mathrm{M}$, et al. A case-control study of lung cancer with special reference to asbestos exposure Environ with special reference to as

16 Siemiatycki J. Risk factors for cancer in the workplace. Boca Raton: CRC Press, 1991.

17 Bovenzi M, Stanta G, Antiga G, Peruzzo P, Cavallieri F. Occupational exposure and lung cancer risk in a coastal area of Northeastern Italy. Int Arch Occup Environ Health 1993;65:34-41.

18 Karjalainen A, Antrila S, Vanhala E, Vainio H. Asbestos exposure and the risk of lung cancer in a general urban population. Scand $f$ Work Environ Health 1994;20: 243-50

\section{Correspondence and editorials}

Occupational and Environmental Medicine welcomes correspondence relating to any of the material appearing in the journal. Results from preliminary or small scale studies may also be published in the correspondence column if this seems appropriate. Letters should be not more than 500 words in length and contain a minimum of references. Tables and figures should be kept to an absolute minimum. Letters are accepted on the understanding that they may be subject to editorial revision and shortening.

The journal also publishes editorials which are normally specially commissioned. The Editor welcomes suggestions regarding suitable topics; those wishing to submit an editorial, however, should do so only after discussion with the Editor. 